\title{
The Preparation of Secondary School Mathematics Teachers in South Africa: Prospective Teachers' Student Level Disciplinary Content Knowledge
}

\author{
Jogymol Kalariparampil Alex ${ }^{1^{*}}$ \\ ${ }^{1}$ Walter Sisulu University, SOUTH AFRICA \\ Received 9 February 2018 - Revised 15 March 2019 - Accepted 17 March 2019
}

\begin{abstract}
Teachers' content knowledge impacts on what they teach, how they teach and what their students learn. In order to check whether the prospective teachers in a rural South African university know the mathematics content they are expected to teach in the schools, at least at the same depth as their future students expected to attain, the research on the Student-Level Disciplinary Content Knowledge (SLDCK) of a sample of 40 Bachelor of Education (Mathematics) students was conducted. The theoretical framework rests on theories on subject content knowledge of pre-service teachers. The data were generated from the performance of the prospective teachers in two tests on the selected topics in the South African senior secondary school mathematics curriculum and also from document analysis. It was found that the prospective teachers had only limited SLDCK on the topics that they were meant to teach in the schools. An in-depth analysis of the course modules offered at the university also revealed that the prospective teachers' limited SLDCK was due to the curriculum constraints of the university. Effective teaching measures to close the gap in the SLDCK and changes in the teacher training curriculum of the university are recommended to enhance the preparation of prospective teachers of the country.
\end{abstract}

Keywords: student-level disciplinary content knowledge, mathematics education, prospective teachers

\section{INTRODUCTION}

Pre service training is an internship period all teachers go through to be prepared for the profession and research about improving the quality of teaching is important (Gokalp, 2016). Over the time, researchers have come to recognise that the issues surrounding teachers' knowledge, in general, and its implementation in classroom practice, in particular, are multifaceted and complex (Mewborn, 2001). According to a number of research studies, teachers' content knowledge makes a difference in their instructional practice and their students' achievement. Ball, Thames and Phelps (2008) advocate that teachers must know the subject they teach as the teachers who do not themselves know a subject well are not likely to have the knowledge they need to help students learn that content. Roberts-Hull, Jensen and Cooper (2015) state that the ways in which candidates are prepared to be teachers have a critical influence on what teachers can do and what their students learn, yet very few countries have an effective system for educating teachers. They also speak of a situation in Australia that some teacher preparation programs do not provide the necessary content knowledge required to adequately teach the curriculum. Mewborn (2001) aver that in America, what types of knowledge are essential for teaching mathematics in the elementary school has been a research area for the last 40 years. Qualified pre service teachers in the teaching profession and their competency are very important for effective outcomes (Gokalp, 2016: 504). To teach mathematics effectively, teachers must have good mastery of the substantive and syntactic structures of mathematics. They must not only be capable of telling students the accepted facts, concepts and principles of different branches of mathematics, they must also be able to explain to students why a particular mathematical principle is deemed warranted, why it is

(C) 2019 by the authors; licensee Modestum Ltd., UK. This article is an open access article distributed under the terms and conditions of the Creative Commons Attribution License (http://creativecommons.org/licenses/by/4.0/). 凹jalex@wsu.ac.za (*Correspondence) 


\section{Contribution of this paper to the literature}

- Student level disciplinary content knowledge is important for a teacher because if a teacher does not know what to teach, their students are not going to learn what they are meant to learn.

- Teacher education courses in many countries tend to be at an advanced level and this study sheds light into the importance of pre-service teachers knowing the content at least at the same depth as the students they are expected to teach at a particular grade level.

- The results of the study also show that there is a dire need for teacher education courses to be adjusted according to the curriculum changes in the school.

worth knowing and how it relates to other principles within the same branch and across other branches of mathematics (Tsang \& Rowland, 2005). Roberts-Hull et al. (2015) affix that high-performing education systems place a greater emphasis on subject-specific expertise, particularly content knowledge. In Finland, all teachers are expected to have a master's degree in the subject they teach. Trainee teachers in Singapore must attain the content knowledge of a specialist degree in the subject (Roberts-Hull et al., 2015). Research by Bukova-Güzel, CantürkGünhan, Kula, Özgür, and Elçí (2013) espouse that content specific knowledge domains for mathematics teachers can be named as mathematics subject-matter knowledge, mathematics curriculum knowledge and mathematical pedagogical content knowledge. Designers of professional development for mathematics and science teachers are faced with many decisions related to the content they choose to address, the selection of strategies to reach professional development goals, and how they facilitate transfer of teachers' new knowledge to their classroom practice (Pasley, 2011: 3). However, warranting that teachers have a satisfactory understanding of all the specific concepts they have to teach is clearly a necessity. This motivated the researcher, who is a Mathematics Education lecturer in a South African rural university to investigate the content knowledge of prospective teachers who are taught specific topics in their four year of Bachelor of Education Course pertaining to senior secondary school in South Africa.

\section{THE SOUTH AFRICAN CONTEXT}

It is well-known that in South Africa, the majority of learners achieve extremely poorly in Mathematics (Pournara, Hodgen, Adler, \& Pillay, 2015). Kriek and Grayson (2009) assert that the poor state of mathematics and science education in South Africa can be attributed, in part, to many teachers' limited content knowledge, ineffective teaching approaches and unprofessional attitudes. The study conducted by Legotlo, Maaga, and Sebego (2006) to investigate the perceptions of stakeholders on causes of poor performance in Grade 12 National Examinations based on a rural province in South Africa inferred that one of the factors contributing to the poor performance of Grade 12 learners was the shortage of experienced and qualified educators. It also has been noted by many research studies that teachers don't know well enough the mathematics their learners need to learn (Bansilal, Brijlall, \& Mkhwanazi, 2014). In the National Senior Certificate (NSC) Diagnostic Report published by the Department of Basic Education (DBE) on the NSC examination of 2014, it was mentioned that the deficiency in understanding specific subject content areas is a problem in many schools and it appears to be compounded by a shallow grasp of some of these content areas by teachers, or by teachers neglecting to cover certain aspects of the curriculum. The poor quality of responses even in lower order questions suggests that some of the candidates were not adequately exposed to the relevant content (DBE, NSC Diagnostic Report, 2014). According to Schools Subject Report (2015) on NSC Examinations of 2014, the national performance of learners on the key subjects, Mathematics was the worst performing subject in 2011(46,3\%), 2012 (54\%), $2013(59,1 \%)$ and $2014(53,5 \%)$. These percentages are the percentages of learners who achieved a minimum of $30 \%$ pass requirement. Many claim that one of the causes of this poor attainment is teachers' weak knowledge of mathematics, and propose that improving teachers' mathematical knowledge would improve learner attainment (Pournara, Hodgen, Adler, \& Pillay, 2015).

South African Education system is confronted by many curriculum reforms since its democratic inception in 1994. Ever since it has focused a great deal of time and attention on teacher preparation as many policy documents are based on the logical assumption that teachers' content knowledge has a significant influence on student learning. Teaching strategies, content knowledge, understanding and motivation were some of the factors identified by Mji and Makgato (2006) on their study on the factors associated with the poor performance of South African learners in mathematics and physical sciences and they suggest that learners can be motivated towards the subject if educators are confident with respect to knowledge of the subjects they teach. In the interaction with Department of Basic Education (DBE), there seem to be an understanding that the teachers have low content knowledge in Mathematics. Many diagnostic reports on matric examination analysis (see 2014 NSC Diagnostic Report, Schools Subject Report 2015) suggest that to address the deficiency in many subject content areas in matric exams, meaningful and effective interventions at the teacher level to be prioritised. This is affirmed by the report on the initial teacher education training in South Africa as Taylor (2018) has noted that the state of the initial teacher 
education (ITE) sector as far from healthy and it calls for the courses at universities to be revamped for student success in school mathematics. Earlier, a study conducted on the Intermediate Phase (IP) (Grades 4-6) teacher education courses in five universities in South Africa reported very low mathematics knowledge by the students entering the B.Ed. programme referring to student teachers mostly only managing mathematics content at the IP level (Bowie \& Reed, 2016). Moreover, the Eastern Cape Province is characterized by very high failure rate in school mathematics that has prevailed despite various interventions in the field. The relationship between the high failure in Eastern Cape and the initial teacher education course for senior secondary school teaching (Grades 10-12) in the university situated in the Eastern Cape has to be studied in this context and this paper looks at course modules and the subject content knowledge of the student teachers trained at the university to find possible solutions to the scenario alluded so far.

It is noted from the work of Shulman (1986) that testing the teacher for subject matter show how our teacher knowledge is defined. Since the seminal work of Shulman, much has been talked on the subject content knowledge of pre-service student teachers (see for example, Ball, Thames and Phelps, 2008; Thanheiser, Browning, Moss, Watanabe, \& Garza-Kling, 2010). A notion of 'mathematical knowledge for teaching' (MKT) framework became more dominant when discussing these different types of knowledge that preservice teachers to develop in order to teach mathematics in schools. A rather refined subject content knowledge defined by Pasley (2011) known as Student-Level Disciplinary Content Knowledge (SLDCK) talks about teachers' own understanding of the content they are expected to teach at a particular grade level. In South Africa, what the students are expected to learn in a particular grade level is explained in the Curriculum and Assessment Policy Statement (CAPS) documents published by the Department of Basic Education (DBE). Only a few studies have examined the relationship between teacher content knowledge and student achievement in Mathematics in South Africa. In this context, a research on the Student-Level Disciplinary Content Knowledge (SLDCK) of the pre-service teachers from a rural university in one of the underperforming areas was warranted as enhancing the SLDCK of the future teachers of the country can be taken as a measure to promote the students' success. Therefore, in an attempt to find out prospective teachers' understanding of the content mainly in the seven topics they are expected to teach at secondary school level and to give remedial measures, this research was embarked. The research questions addressed were (a) how much Student-Level Disciplinary Content Knowledge (SLDCK) do the third year Mathematics Education pre-service teachers do have just before they go for their five weeks of teaching practice? (b) Does the Mathematics Education curriculum support the SLDCK of the third year Mathematics Education prospective teachers in relation to what they are supposed to teach in the schools?

\section{THEORETICAL FRAMEWORK}

An era of scholarly and practical work on teacher content knowledge emerged in 1986 when Shulman proposed five content-specific domains of teacher knowledge (Pasley, 2011). The writings of Shulman in the 1980's talk of content knowledge as "the amount and organisation of knowledge in the minds of a teacher" (Shulman, 1986, p. 9) and Pedagogical Content Knowledge (PCK) as a particular form of content knowledge that embodies the aspects of content most germane to its teachability. For Shulman (1986), PCK also refers to the conceptions and preconceptions that students of different ages and backgrounds bring with them to the learning of those most frequently taught topics and lessons. Within the category of PCK, Shulman includes "the knowledge for the most regularly taught topics in one's subject area, the most useful forms of representation of those ideas, the most powerful analogies, illustrations, examples, explanations, and demonstrations-in a word, the ways of representing and formulating the subject that make it comprehensible to others" (Shulman, 1986, p.9). Researchers have used PCK to refer to a wide range of aspects of subject matter knowledge and the teaching of subject matter and, indeed, have used it differently across-and even within-subject areas (Ball, Thames, \& Phelps, 2008). For Shulman (1986: 9), content knowledge refers to what a teacher knows, how much s/he knows and what s/he should know (Ball \& McDiarmid, 1990). Brophy (1991) as cited in Mapolelo and Akinsola (2015: 507) contends that "when teachers' knowledge of the subject that they teach (subject content knowledge) is rich, integrated and accessible, they tend to teach the subject more dynamically by using more varied ways (pedagogical content knowledge) while encouraging and responding more fully to learners' questions and comments". There is a general agreement that teachers need to know the disciplinary content they teach, but there are multiple points of view on what it means to know that content, or what is the appropriate way for teachers to know it (Pasley, 2011). As a result, even though, it is mentioned earlier in the previous section that the wide spread notion of the 'Mathematical Knowledge for Teaching' (MKT) with it domains as espoused by Ball, Thames and Phelps (2008) foregrounds the entire study by the researcher, the particular aspect of subject content knowledge as noted by Parsley (2011) was taken as the theoretical perspective for this paper. According to Pasley (2011), the views on the subject content knowledge, tend to fall into three different levels of content knowledge: (1) knowledge of student-level disciplinary content; (2) knowledge of advanced disciplinary content; and (3) knowledge of profound disciplinary content. The StudentLevel Disciplinary Content Knowledge (SLDCK) is teachers' own understanding of the content they are expected 
to teach at a particular grade level. Pasley (2011) observes that one of the effects of curriculum changes is that teachers may be unfamiliar with content ideas they are required to teach at their own grade level. The argument for developing teachers' knowledge of disciplinary content at the student level emphasizes the importance of teachers' understanding the content they are expected to teach, at least at the same depth students are expected to attain at that grade. After closely examining the body of literature on the different types of teacher knowledge (Ball \& McDiarmid, 1990; Ball, Thames, \& Phelps, 2008; Pasley, 2011; Shulman, 1986; Thanheiser, Browning, Moss, Watanabe, \& Garza-Kling, 2010) that links with student learning, this study adopted that Pasley's (2011) framework of SLDCK of mathematics is the kind of content knowledge that the pre-service Mathematics Education students need to possess as emerging mathematics teachers for South African schools, more especially in the special context of Eastern Cape.

\section{METHODS}

This research adopted a positivist paradigm and a quantitative approach. The design was descriptive analysis. This paper reports part of a larger study on the different aspects of the mathematics teacher education programme as being studied, explored and reported in a rural university in South Africa. The sample used for this part of the study consisted of third year university Bachelor of Education (Mathematics Education) cohort of 40 students, who voluntarily took part in the study out of the 104 students registered for the mathematics major course. Most of these prospective teachers had their senior secondary school education in the underprivileged rural schools in the Eastern Cape. The entry requirement for the Mathematics Education (for Bachelor of Education) is that the applicants must have passed Mathematics in Grade 12 with a t least Level 4 (50\%) and above. While they were at schools, they were following the National Curriculum Statement (NCS) curriculum. During their third year of study the school curriculum was changed to Curriculum and Assessment Policy Statement (CAPS) which had new demanding topics such as Financial Mathematics, Probability, and Euclidean Geometry which they had not learnt at schools. It was also evident from the documents on the Year 1 and Year 2 university Mathematics Education curriculum that the prospective teachers were not taught with the topics they missed in the schools. The research was on assessing the prospective teachers' SLDCK on the selected topics which they are meant to teach in the schools, before the actual teaching at the schools for their five weeks of School Based Experience (SBE) (SBE - commonly known as Teaching Practice). In consultation with the prospective teachers and the Pace Setter of the school curriculum for the five weeks they are meant to be at school, the topics for the SLDCK Test were selected. A standardised Mathematics question paper comprised of the National Senior Certificate (NSC) Matric Examinations of November 2014 was purposively selected. Due to page constraints, the question paper is not attached to this article. It is available from www.ecexams.ac.za. This diagnostic test was conducted as two tests due to time constraints and to differentiate between Paper 1 and Paper 2 of the school mathematics curriculum. Two question papers of which one consisting of three questions on Financial Mathematics and Probability and the other one consisting of 10 questions on Data Handling, Analytical Geometry, Trigonometry and Euclidean Geometry provided the data to answer the first research question of the study. TEST 1 (Paper 1) was out of 29 marks. Question 1 was on the topic of Financial Mathematics (13 marks) and Questions 2 and 3 were on Probability with 16 marks. These questions were Question 7, Question 11, and Question 12 respectively of the NSC Mathematics Matric Examination of 2014. TEST 2 (Paper2) was out of 150 marks which were exactly the same questions of NSC Mathematics Matric Examination of 2014 Paper 2 with Question 1, Question 2 on Data Handling (20 marks) Question 3, Question 4 on Analytical Geometry (40 marks); Question 5, Question 6, Question 7 on Trigonometry (40 marks) and Question 8, Question 9, Question Q10 on Euclidean Geometry (50 marks). A formula sheet was also provided. The test was conducted during the Mathematics Education lessons. The second research question was addressed through document analysis. Permission was sought and obtained from the faculty and all the ethical requirements were met.

\section{DATA ANALYSIS, RESULTS AND FINDINGS}

\section{Analysis of the Prospective Teachers' Performance in Individual Topics}

The two tests were marked according to the memorandum of National Senior Certificate (NSC) Matric Examinations of November 2014. The individual marks for each question was then captured and analysed using Microsoft Excel 2013.

Figure 1 shows the average percentages in SLDCK Test of the sample in the 6 topics selected for the study.

It was noted that the average percentages for Financial Mathematics was 52\%, Probability was 20\%, Data Handling was 35\%, Analytical Geometry was 37\%, Trigonometry was 28\%, Euclidean Geometry was $16 \%$ and the total aggregate percentage was $27 \%$. It was also noted from the analysis of average percentages of each topic, Euclidean geometry was the worst performed topic as the average percentage for geometry was only $16 \%$. 


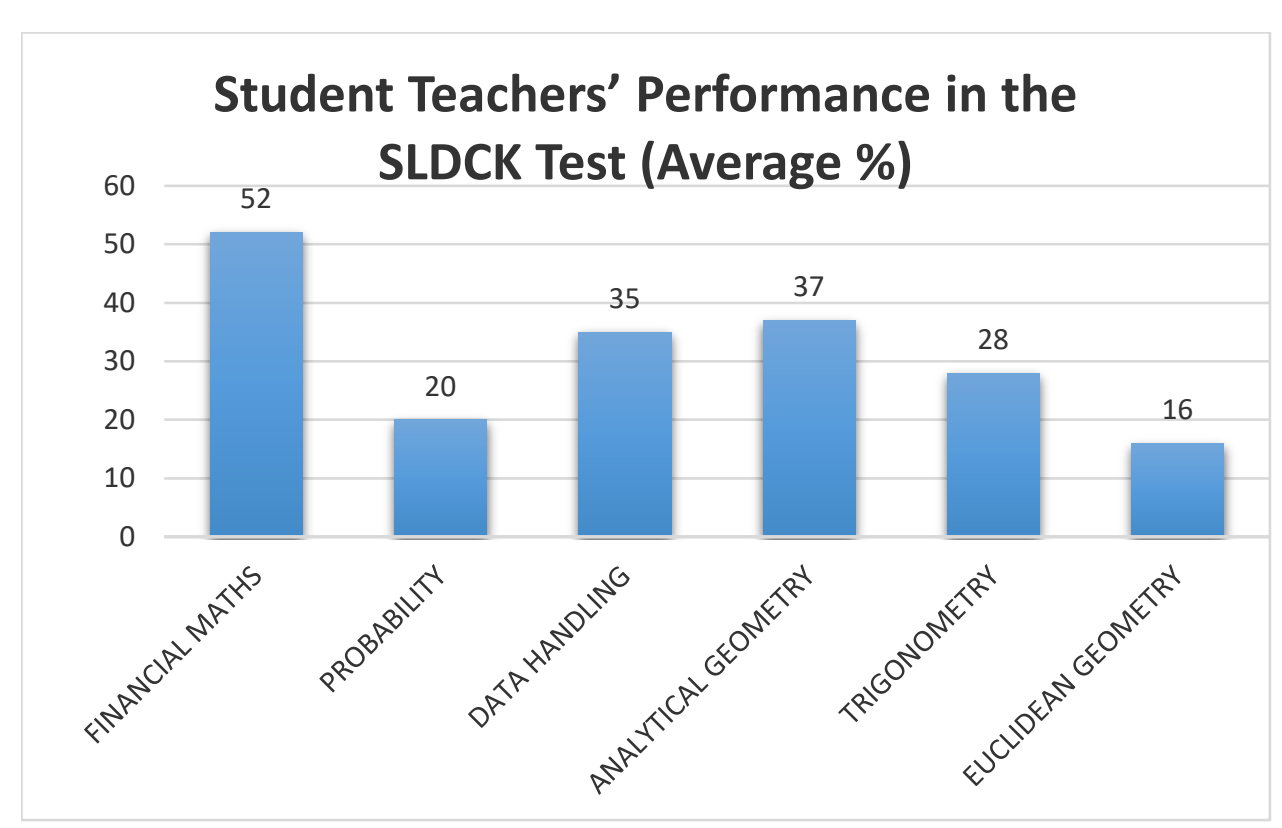

Figure 1. Prospective teachers' Performance in the SLDCK Test: Average percentages

Probability was also one of the low performing topics with an average percentage of $20 \%$. From the analysis, it is noted that the prospective teachers had only limited SLDCK on the topics that they were meant to teach in the schools during their School Based Experience.

\section{Analysis of Prospective Teachers' Performance According to Levels in the Test}

A further analysis was carried out to see the levels in which the prospective teachers performed in the test.

According to the levels described by DBE (2011), the mark ranges are as follows: 0 - 29: Level 1; 30 - 39: Level 2; 40 - 49: Level 3; 50 - 59: level 4; 60 - 69: level 5; 70 - 79: level 6 and 80 - 100: level 7. In mathematics, Level 1 is considered as a failure. According to the level analysis 27 students out of 40 (67.5\%) failed the Paper 1 and Paper 2 Tests and only three students (7.5\%) managed to get more than $50 \%$. This analysis is shown in Table 1.

Table 1. Prospective teachers' SLDCK on selected topics: Performance in Papers 1 and 2

\begin{tabular}{cccccc}
\hline \multirow{2}{*}{ Interval of Marks } & \multirow{2}{*}{ Level } & \multicolumn{2}{c}{ Paper 1 Test } & \multicolumn{2}{c}{ Paper 2 Test } \\
\cline { 3 - 6 } & 1 & Number of students & \% & Number of students & $\%$ \\
\hline $0-29$ & 2 & 27 & 67.5 & 27 & 67.5 \\
\hline $30-39$ & 3 & 2 & 20 & 8 & 20 \\
\hline $40-49$ & 4 & 0 & 5 & 2 & 5 \\
\hline $50-59$ & 5 & 3 & 7.5 & 3 & 0 \\
\hline $60-69$ & 6 & 0 & 0 & 0 & 0 \\
\hline $70-79$ & 7 & 0 & 0 & 0 & 0 \\
\hline $80-100$ & & 40 & 100 & 40 & 100 \\
\hline TOTAL & & & 0 & 0 & 0 \\
\hline
\end{tabular}

As SLDCK talks about teachers' own understanding of the content they are expected to teach at a particular grade level, a further analysis was carried out to compare the student teachers' performance against that of the South African Martic Students (Grade 12) of 2014. This is to check whether the student teachers possess the same SLDCK on the same topics as that of the students who wrote the same exam in 2014. The matric examinations in South Africa are set according to the content in the CAPS document. The data for the South African martic students of 2014 were obtained from the Diagnostic Report, NSC 2014, published by the Department of Basic Education, Republic of South Africa.

Tables 2 and $\mathbf{3}$ are shown separately to show the different content areas (topics) in the separate question papers on Paper 1 and Paper 2 which were tested separately as Test 1and Test 2 . The interpretation of the two are also mentioned underneath each table.

In test 1 (Paper 1), on the answering of the topic Financial Mathematics, the average percentage of prospective teachers was $52 \%$. The prospective teachers generally showed misunderstanding in the common concepts and language of finance lead them to use incorrect formulae. This resulted in their low performance in the topic. 
Table 2. PAPER 1: Questions: Topic-wise analysis and performance comparison between student teachers and Matric 2014 students

\begin{tabular}{lclc}
\hline Question number and source & $\begin{array}{c}\text { Total mark for } \\
\text { each question }\end{array}$ & Items / concepts tested & $\begin{array}{c}\text { Prospective } \\
\text { teachers' average \% } \\
\text { in each question }\end{array}$ \\
$\begin{array}{l}\text { Question 1 (Question 7 of NSC, December } \\
\text { 2014) }\end{array}$ & 13 & $\begin{array}{c}\text { Matric 2014 } \\
\text { in each question }\end{array}$ \\
\hline $\begin{array}{l}\text { Question 2 (Question 11 of NSC, 2014) } \\
\text { interest }\end{array}$ & 52 & 56 \\
\hline Question 3 (Question 12 of NSC,2014) & 7 & $\begin{array}{l}\text { Probability, dependent/independent } \\
\text { events }\end{array}$ & 32 \\
\hline
\end{tabular}

Table 3. PAPER 2: Questions: Topic-wise analysis and performance comparison between student teachers and Matric 2014 students

\begin{tabular}{|c|c|c|c|c|}
\hline Question number and Topics & $\begin{array}{l}\text { Total mark for } \\
\text { each question }\end{array}$ & Items / concepts tested & $\begin{array}{c}\text { Prospective } \\
\text { teachers' average \% } \\
\text { in each question }\end{array}$ & $\begin{array}{c}\text { Matric } 2014 \\
\text { students' average \% } \\
\text { in each question }\end{array}$ \\
\hline Question 1: Data Handling & 12 & $\begin{array}{l}\text { Standard deviation, Regression line, } \\
\text { outliers }\end{array}$ & 23 & 69 \\
\hline Question 2: Data Handling & 8 & Mode, Cumulative frequency, Ogive & 52 & 61 \\
\hline Question 3: Analytical Geometry & 21 & $\begin{array}{l}\text { Gradient, equation of the tangent, } \\
\text { equation of a circle }\end{array}$ & 41 & 57 \\
\hline Question 4 : Analytical Geometry & 19 & $\begin{array}{l}\text { Coordinates of a point, angle, } \\
\text { equation of a straight line, area of a } \\
\text { quadrilateral }\end{array}$ & 32 & 42 \\
\hline Question 5: Trigonometry & 9 & $\begin{array}{l}\text { Angles and distances using } \\
\text { trigonometry }\end{array}$ & 34 & 57 \\
\hline Question 6: Trigonometry & 12 & Proving identity, compound angles & 21 & 34 \\
\hline Question 7: Trigonometry & 19 & $\begin{array}{l}\text { Trigonometric graphs and } \\
\text { interpretations }\end{array}$ & 29 & 37 \\
\hline Question 8: Euclidean Geometry & 14 & $\begin{array}{l}\text { Circle geometry theorems and } \\
\text { applications }\end{array}$ & 41 & 59 \\
\hline Question 9: Euclidean Geometry & 16 & $\begin{array}{l}\text { Proportional intercepts and similar } \\
\text { triangles theorems and applications }\end{array}$ & 8 & 38 \\
\hline Question 10: Euclidean Geometry & 20 & $\begin{array}{l}\text { Application of circle geometry and } \\
\text { similar triangles theorems }\end{array}$ & 7 & 34 \\
\hline
\end{tabular}

Source for Matric 2014 student' average performance data: Diagnostic Report, NSC 2014

In the case of answering Probability questions (Questions $2 \& 3$ ), the average percentages of prospective teachers were $32 \%$ and $11 \%$ respectively. Incorrect use of notations due to the lack of unfamiliarity was evident in most of the prospective teachers' scripts. Most of them could not even attempt questions on counting principles.

In Test 2 (Paper 2), Question 1 tested the understanding of the mean, standard deviation, regression line equation and outliers. Question 2 tested the understanding of the cumulative frequency and the ogive. In answering these questions, the average percentages of prospective teachers were $23 \%$ and $52 \%$ respectively. Most of the prospective teachers did not answer questions on one standard deviation of the mean, equation for the least squares regression line and identification of outliers. Even though majority of the prospective teachers could draw the ogive, but could not answer the follow up question on it. Lack understanding in unfamiliar concepts- the concepts they did not follow in the curriculum they were trained with when they were in their senior secondary schools might have contributed to this low achievement.

Question 3 and Question 4 of Paper 2 in Test 2 were on Analytical Geometry (40 marks) and Question 3 tested the understanding of circle and question 4 tested the understanding of equations, angles and polygons in Coordinate Geometry. In answering these questions, the average percentages of prospective teachers were $41 \%$ and $32 \%$ respectively. The prospective teachers struggled to get to answer the sub follow up questions as they could not carry forward the answers to follow up questions. Finding the equation of the circles and areas of polygons was a major problem to many prospective teachers. The integration of Euclidean geometry in to solving Analytical Geometry questions were seemed to be an issue for majority of the prospective teachers.

Question 5, Question 6 and Question 7 in Test 2 (Paper2) were on Trigonometry (40 marks) where question 5 tested the understanding in solutions of triangles and Question 6 tested the proof and use of compound angle and other identities to solve and prove identities and Question 7 tested the understanding of trigonometric functions with its interpretation. In answering these questions, the average percentages of prospective teachers were $34 \%$, $21 \%$ and $29 \%$ respectively. Lack of basic skills in trigonometry such as angle identification, use of correct formula and substitution with correct values were evident in the scripts. Reduction formula and interpretation and transformation of the trigonometric graphs were also a problem for majority of the prospective teachers. 
Question 8, Question 9 and Question 10 of Paper 2 in Test 2 were on Euclidean Geometry (50 marks) and Question 8 tested the circle geometry theorems, Question 9 tested the proof of proportionality theorems and its applications and Question 10 tested Circle geometry and similarity and its applications. In answering these questions, the average percentages of prospective teachers were $41 \%, 8 \%$ and $7 \%$ respectively. Even though Question 8 was attempted fairly well, questions 9 and 10 were not even attempted by majority of the prospective teachers. Circle geometry and similarity and its applications were the worst answered question in the whole paper.

It is noted from the Tables 2 and 3 that the performance of the prospective teachers in all the questions were much lower than that of the matric students of 2014.

To further investigate whether it was due to the courses taught to them, an analysis of the mathematics content curriculum was carried out.

\section{Analysis of the Modules Taught}

A close examination on the content of the modules taught for the Mathematics Education was needed, as most of the students after seeing their performance in the SLDCK Test indicated that the content needed in the school was lacking in their curriculum. This made to further investigate on the curriculum and the training given to the Mathematics Education students at the university. This was done through document analysis. The prospectus for the Mathematics Education BEd course revealed that it is only during the first year of the study that the students were taught with mathematics content of the senior secondary schools through a yearlong course module called Introduction to Curriculum Studies. During the second year and the third year of the study, the students are taught by the service department of Mathematics and Applied Sciences. In the second year of the study, in Mathematics I, students are taught with Calculus I and Pre- Calculus II, where functions and introduction to calculus is taught. In the third year of the study students are taught in Mathematics II with 4 main topics such as Multivariate Calculus, Real Analysis, Ordinary Differential Equations and Linear Algebra and these unrelated topics have nothing in common with the senior secondary school mathematics curriculum except for algebra, functions and calculus. In the third year of the study, the student teachers are also taught with Curriculum Studies in which methods are taught (A brief history of mathematics, Methods and Approaches in the teaching and learning of mathematics, Philosophies of mathematics: Assessment and Evaluation, Lesson planning covering senior secondary school Topics, Microteaching) and five weeks School Based Experience (SBE) in the third term of the school calendar. Fourth year of the study is mainly School Based Experience and the submission of a Research Paper based on the teaching context where the students get engaged in. The School Based Experience is done at schools for six months in the second semester of the year.

The CAPS curriculum in the senior secondary school has 10 major topics. Namely, Functions, Number patterns, Sequences and Series, Finance, Growth and Decay, Algebra, Differential Calculus, Probability, Euclidean Geometry and Measurement, Analytical Geometry, Trigonometry and Statistics.

It was noted from the course modules that the mathematics content curriculum followed in the schools was not stressed in the modules. Even though in the first year of study, senior secondary school mathematics was the content for their course modules, the students were not taught with the topics of Geometry and Probability as they were following the NCS curriculum at that time and during their third year of study, they had to teach the topics in schools as these topics were part of the CAPS curriculum, which was not catered for in their modules. It should also be noted from the course modules that in the second year and third years of study, only a portion of the topics namely, Functions and Calculus were taught and the students had to study totally unrelated topics which did not support the school mathematics.

\section{DISCUSSIONS}

Lack of understanding in basic skills and usage of incorrect formulae were the main problems in answering the question by the matric students of 2014 as reported by the chief markers, internal moderators and subject specialists post the marking process of the 2014 NSC exam according to NSC Diagnostic Report (DBE, 2014). Prospective teachers also had similar difficulties in answering the same questions. One of the implications as suggested by the above report was that the teachers themselves are unfamiliar with the concepts and suggest that to address the deficiency in many subject content areas in matric exams, meaningful and effective interventions at the teacher level to be prioritised. The study also concurs with Mapolelo and Akinsola (2015, p.507) who refer to Simmons (1993) who contends that, "In order to teach well the teacher needs to know about the subject matter in both width and depth to a degree unlikely to be found amongst those beginning a teacher training course" (p. 9). The study also affirms the findings by Ball, Lubienski and Mewborn (2001) in USA that our prospective teachers have insufficient understanding of the mathematical knowledge it takes to teach well. The study by Ball et al (2008) on mathematical knowledge needed to perform the recurrent tasks of teaching mathematics to students concluded that teachers who do not themselves know a subject well are not likely to have the knowledge they need to help 
students learn this content. Brown and Borko (1992) also contended that teachers teach as they have been taught. Hashweh (1987) as cited in Yilmaz (2016) ascertain that prospective teachers with incorrect and insufficient knowledge might transfer those misconceptions to their students. The present study points towards the vicious cycle of the teacher education system in South Africa and elsewhere that if a teacher does not know what to teach, the students are not going to learn what they are meant to learn.

Shulman (1986: 9) describes content knowledge as what a teacher knows, how much s/he knows and what s/he should know. In terms of the subject content knowledge that the student teachers need to have, Pasley's (2011) refined version, Student-Level Disciplinary Content Knowledge (SLDCK) talks about teachers' own understanding of the content they are expected to teach at a particular grade level. The average percentages obtained by student teachers for the matric examination which was set according to the content in the CAPS document were $52 \%$ (Financial Mathematics), 20\% (Probability), 35\% (Data Handling) 37\% (Analytical Geometry), 28\% (Trigonometry), $16 \%$ (Euclidean Geometry) and 27\% total aggregate percentage. In this premise, the data seem to suggest that student teachers are not even achieving the notion of subject content knowledge and mathematical knowledge for teaching as suggested by Parsley (2011) in terms of SLDCK. The interpretation that the prospective teachers' misunderstanding in the common concepts, lack of understanding in unfamiliar concepts and incorrect use of formulae show that the prospective teachers did not possess the necessary SLDCK that they were meant to have while they were on their SBE. The analysis of the content modules taught to the Mathematics Education students showed that they were being taught with advanced level of mathematics topics known as university mathematics, but their performance in the school level mathematics showed that it could not help the prospective teachers to address the content which is in their students' level (SLDCK). It is also in line with Ball et al (2008), who assert that it seems unlikely that just knowing more advanced mathematics will satisfy all of the content demands of teaching. According to Pasley (2011), “the argument for developing teachers' knowledge of disciplinary content at the student level emphasizes the importance of teachers understanding the content they are expected to teach, at least at the same depth students are expected to attain at that grade" (p.4). The prospective teachers' performance was even worse than the school students. Even though knowledge of mathematics and knowledge of mathematics teaching have something in common (Couto \& Vale, 2014), and are being addressed through the course modules, our prospective teachers are still not reaching the standards they are supposed to attain in the content specific areas. This confirms the inference with Ball et al (2008) that "although there are exceptions, the overwhelming majority of subject matter courses for teachers, and teacher education courses in general, are viewed by teachers, policy makers, and society at large as having little bearing on the day-to-day realities of teaching and little effect on the improvement of teaching and learning" (p.404).

The ongoing curriculum revision in South Africa also had a major impact on the prospective teachers' performance. Pasley (2011) averred that developers of instructional materials respond to curriculum changes by adding new topics or moving topics from one grade level to another and the consequence of such reform is that teachers may be unfamiliar with content ideas they are required to teach at their own grade level. The same situation was met by the prospective teachers in this study. According to Pasley (2011), this level of knowledge has not typically been the direct focus of academic work because its inevitability is generally taken for granted. This could have been the reason that for many teacher education courses believed to be at the advanced level rather than being adjusted according to the curriculum changes in the school level.

The results of this study raises a major concern on the part of the prospective teachers on their content knowledge, as Shulman (1987: 8) opines that the teachers have special responsibilities in relation to content knowledge, serving as a primary source of student understanding of subject matter. This study concurs with the inference of Ball et al. (2008) that subject matter courses in teacher preparation programs tend to be academic in both the best and worst sense of the word, scholarly and irrelevant, either way remote from classroom teaching. It has also been noted from the writings of Shulman (1986) that decades ago, even in the United States of America, the situation was that those who knew the teaching procedures became teachers and little importance was given to knowing the content of the curriculum. This mismatch is still being followed even in South African Universities. Thus the analysis of studies on teachers' content knowledge everywhere prove that our teacher education system is charectrised by an inertia that it does not want to correct and learn from the past.

\section{CONCLUSIONS}

This study is novel as it tried to find out Student-Level Disciplinary Content Knowledge (SLDCK) of the preservice teachers and to compare it with the matric students' content knowledge in the selected topics of a martic exam as that of matric students who originally wrote the exam. The findings lead to make conclusions on connections between the performances of the students in the test due to the curriculum constraints of the university and the students own inability to acquire the content knowledge they need to have as teachers. It is noted that the $3^{\text {rd }}$ year Mathematics Education students do not possess the required SLDCK to teach in the senior secondary schools and the advanced level mathematics curriculum of the university does not support the demands the 
prospective teachers when they are at schools for their teaching practice. It can also be noted that the ongoing curriculum revision in South Africa also had a major impact on the prospective teachers' performance.

\section{RECOMMENDATIONS}

The trainers of teacher education need to address their pre-service teachers' SLDCK in mathematics. It should be taught as if they are learners of mathematics themselves. To match with the demands and requirements, the reforms in the school curriculum should be followed by how the teachers should be educated in the university. The curriculum for the content preparation of teachers in the university should include more opportunities for the Mathematics Education students to familiarise with the school mathematics content so as to prepare them well as emerging teachers. A better understanding of the type of content knowledge for teaching should inform the design of the curriculum and the support materials for pre service teachers.

\section{REFERENCES}

Ball, D. L., Lubienski, S., \& Mewborn, D. (2001). Research on teaching mathematics: The unsolved problem of teachers' mathematical knowledge. In V. Richardson (Ed.), Handbook of research on teaching (pp. 433-456). New York, NY: Macmillan.

Ball, D. L., Thames, M. H., \& Phleps, G. (2008). Content Knowledge for Teaching: What Makes It Special? Journal of Teacher Education, 59(5), 389-407. https:/ / doi.org/10.1177/0022487108324554

Ball, D., \& McDiarmid, G. W. (1990). The subject Matter Preparation of Teachers. In W. R. Houston, Handbook for Research on Teacher Education. New York: Macmillan.

Bansilal, S., Brijlall, D., \& Mkhwanazi, T. (2014). An exploration of the common content knowledge of high school mathematics teachers. Perspectives in Education, 32(1), 34-50. http:/ / hdl.handle.net/10321/2306

Bowie, L., \& Reed, Y. (2016). How much of What? An analysis of the espoused and enacted mathematics and English Curricula for intermediate phase student teachers at five South African universities. Perspectives in Education, 34(1), 102-119. https:/ / doi.org/10.18820/2519593X/pie.v34i1.8

Brown, C., \& Borko, H. (1992). Becoming a mathematics teacher. In D. A. Grouws (Ed.), Handbook of research on mathematics teaching and learning (209-242). New York: Macmillan.

Bukova-Güzel, E., Cantürk-Günhan, B., Kula, S., Özgür, Z., \& Elçí, A.N. (2013). Scale development for pre-service mathematics teachers' perceptions related to their pedagogical content knowledge, South African Journal of Education, 33(2). https:/ / doi.org/10.15700/saje.v33n2a690

Couto, A., \& Vale, I. (2014). Pre-service teachers' knowledge on elementary geometry concepts. Journal of the European Teacher Education Network, 9, 57-73. Retrieved from http://jetenonline.org/index.php/jeten/article/view/32/57-73

Department of Basic Education (DBE). (2014) NSC Diagnostic Report. South Africa: Seriti Printing.

Gokalp, M. (2016). Investigating Classroom Teaching Competencies of Pre service Elementary Mathematics Teachers. Eurasia Journal of Mathematics, Science $\mathcal{E}$ Technology Education, 12(3), 503-512. https:/ / doi.org/10.12973/eurasia.2016.1296a

International Mathematics Union (IMU). (2014). Mathematics in Africa - challenges and opportunities Report. Retrieved from https://www.mathunion.org/fileadmin/CDC/cdc-uploads/CDC_MENAO/Africa_Report.pdf

Kriek, J., \& Grayson, D. (2009). A holistic professional development model for South African physical science teachers. South African J. Educ., 29, 185-203. http:/ / hdl.handle.net/10500/13479

Legotlo, M. W., Maaga M. P., \& Sebego, M. G. (2002). Perceptions of stakeholders on causes of poor performance in Grade 12 in a province in South Africa. South African Journal of Education, 22, 113-118. https://hdl.handle.net/10520/EJC31866

Mapolelo, D. C., \& Akinsola, M. K. (2015). Preparation of Mathematics Teachers: Lessons from Review of Literature on Teachers' Knowledge, Beliefs, and Teacher Education. American Journal of Educational Research, 3(4), 505513. https://doi.org/10.12691/education-3-4-18

Mewborn, D. (2001). Teachers Content Knowledge, Teacher Education, and their Effects on the Preparation of Elementary Teachers in the United States, Mathematics Education Research Journal, 3, 28-36.

Mji, A., \& Makgato, M. (2006). Factors associated with high school learners' poor performance: A spotlight on mathematics and physical science. South African Journal of Education, EASA, 26(2), 253-266.

Pasley, J. D. (2011). Perspectives on Deepening Teachers' Mathematics and Science Content Knowledge, MSP Knowledge Management and Dissemination. Horizon Research, Inc. 
Pournara, C., Hodgen, J., Adler, J., \& Pillay, V. (2015). Can improving teachers' knowledge of mathematics lead to gains in learners' attainment in Mathematics? South African Journal of Education, 35(3). https:/ / doi.org/10.15700/saje.v35n3a1083

Roberts-Hull, K., Jensen, B., \& Cooper, S. (2015). A new approach: Teacher education reform, Learning First, Melbourne, Australia.

Schools Subject Report. (2015). Published by Department of Basic Education, Republic of South Africa.

Shulman, L. S. (1986). Those Who Understand: Knowledge Growth in Teaching: Educational Researcher, 15(2), 4-14. https://doi.org/10.3102/0013189X015002004

Shulman, L. S. (1987). Knowledge and teaching: Foundations of the new reform. Harvard Educational Review, 57, 122. https:/ / doi.org/10.17763/haer.57.1.j463w79r56455411

Taylor, N. (2018). Teacher Knowledge in South Africa. In N. Spaull \& J. Jansen (Eds.), South African Schooling: The enigma of inequality. Johannesburg: Springer.

Thanheiser, E., Browning, C.A., Moss, M., Watanabe, T., \& Garza-Kling, G. (2010). Developing Mathematical Content Knowledge for Teaching Elementary School Mathematics. IUMPST: The Journal. Vol 1 (Content Knowledge), December, 2010. Retrieved from www.k-12prep.math.ttu.edu

Tsang, F. K. W., \& Rowland, T. (2005). The Subject Matter Knowledge of Hong Kong Primary School Mathematics Teachers, Paper Presented at the European Conference on Educational Research, University College Dublin, 7-10 September 2005.

Yilmaz, N. P. (2016). ICT Student Teachers' Pedagogical Content Knowledge: A Case Study. Eurasia Journal of Mathematics, Science E Technology Education, 12(1), 133-152. https:/ / doi.org/10.12973/ eurasia.2016.1217a

\section{http://www.ejmste.com}

